\title{
UMA NOVELA DE EMIGRAÇÃO?
}

BorIS SCHNADERMAN

Universidade de São Paulo

\section{Resumo}

O texto de Antonio Candido, "Teresina e seus amigos", saiu num livro de ensaios do autor, e realmente pode ser considerado um ensaio, mas, ao mesmo tempo, apresenta características de novela, não obstante o acúmulo de dados factuais, o que poderia levar alguém a incluí-lo na "literatura de testemunho". Tudo isto parece indicar a precariedade das distinções de gênero, em termos de prosa moderna.

\section{Abstract}

Antonio Candido's text "Teresina e seus amigos" was published in a collection of essays by the author and in fact may also be considered an essay. Yet, at the same time, the text contains characteristics of a novel, notwithstanding the accumulation of factual data, which could lead some to include it in the category of "testimonial literature." All of this seems to indicate the precariousness of the distinc-

\section{Palavras-chave}

Experiência pessoal; Ideologia; Questões de gênero tions between genres in modern prose.

\author{
Keywords \\ Personal \\ experience; \\ Ideology; \\ Questions of \\ genre
}


entre os ensaios de Antonio Candido, tenho encantamento especial por um texto que não vi muito citado: "Teresina e os seus amigos", do livro Teresina etc. ${ }^{1}$.

Em primeiro lugar, lembranças pessoais me acodem com a leitura de seu início, onde se diz que a personagem central nasceu em 27 de agosto de 1863, na aldeia de Fontanellato, província de Reggio Emilia. Isto me lembra de imediato aquela manhã luminosa de abril de 1945, quando subimos nos caminhões de meu grupo de artilharia da Força Expedicionária Brasileira (FEB) recém-devolvidos pelos infantes, que os utilizaram para perseguir uma divisão alemã de infantaria e remanescentes de uma divisão italiana, dar-lhes combate e obrigá-los à rendição. Tudo isto aconteceu justamente nas cercanias do local descrito nesse texto, e os que leram meu Guerra em surdina sabem como isto calou fundo em meu espírito. "Liberatori d'Italia! Liberatori d'Italia!" - gritava-nos a população na beira da estrada, e atiravam-nos flores aos punhados. ${ }^{2}$

Pois bem, relendo o texto de Antonio Candido, sinto de novo o vento dos Alpes beliscando-me as orelhas naquela manhã translúcida. Os Alpes, de um azul esmaecido pela distância, e que se viam do outro lado do Vale do Pó.

E a par de minhas lembranças pessoais, surge uma figura feminina, "magra, de estatura média, com um cabelo alourado que custou a embranquecer", de "olhos azuis abertos e redondos, exprimindo de maneira incrível os matizes de um espírito trepidante", enfim um vulto que a fazia passar freqüentemente por inglesa. Isso tanto na Itália como no Brasil, onde acabou se estabelecendo com o marido em 1880.

Eram tempos de crise econômica na Itália, e Guido Rocchi, jovem violoncelista do Scala de Milão, aproveitou uma estada no Rio de Janeiro com a orquestra, para seguir destino diferente.

\footnotetext{
${ }^{1}$ Antonio Candido. Teresina etc. São Paulo, Paz e Terra, 1980, pp. 13-80.

${ }^{2}$ Boris Schnaiderman. Guerra em surdina. 4a ed. São Paulo, Cosac \& Naify, 2004, pp. 181-216.
} 
Sim, fizera parte da orquestra do Scala, onde tivera como colega um jovem "meridional bonitão e cabotino com uma argolinha de ouro na orelha e uma meia verde e outra vermelha" e que se tornaria muito famoso: Pietro Mascagni, cuja obra mais conhecida, a ópera Cavalleria rusticana, era definida por Teresina como uma droga.

Foi, porém, já no Brasil que o casal conheceu outra figura gloriosa da música de seu país, Arturo Toscanini, que havia regido uma orquestra italiana no Rio de Janeiro em 1886, depois que o regente contratado fora vítima de febre amarela, o que possibilitou àquele jovem obscuro de dezenove anos reger orquestra numa apresentação da Aída, episódio que marcaria o início de sua carreira.

Nada disso, porém, impediu os Rocchi de ter profundo entusiasmo pela música alemã (o que era considerado falta de patriotismo) e preferir entre os músicos italianos os instrumentistas dos séculos XVII e XVIII, então pouco estimados.

Boa parte desse texto de Antonio Candido foi dedicado a esmiuçar com espírito crítico um tipo de mentalidade que se formara entre a pequena burguesia da época, favorável a uma alteração completa das condições de vida, visando uma sociedade mais justa e mais humana. Com espírito crítico e, ao mesmo tempo, com muita simpatia.

Teresina era entusiasmada por aquela atitude disruptora e assumia sempre uma postura anticlerical, antirreligiosa até. Simpatizava abertamente com a Rússia soviética, sem qualquer ressalva e sem dar ouvidos aos que, então, já chamavam a atenção para o regime opressivo que se firmava ali.

Isto nos remete diretamente a um tipo que nós da geração de Candido conhecemos bem. Absorvidos completamente por sua atuação, aqueles indivíduos se dedicavam integralmente à luta e, com frequência, eram capazes de sacrificar a própria família em prol do objetivo comum. Teresina evidentemente não era militante, mas tinha o mesmo tipo de mentalidade.

Antonio Candido conheceu-a em Poços de Caldas, como amiga de sua família, visitou-a frequentemente em casa e teve acesso a seus diários e cartas, além de se corresponder com ela.

Nessa época, já estava separada do marido e levava uma vida modesta, ensinando tricô, italiano e francês, e nas horas vagas ficava imersa em leituras e música.

As suas simpatias por uma atitude de esquerda levaram-na a ter contato com ativistas políticos italianos que viveram no Brasil, mas acabaram voltando à Itália, onde apoiaram Mussolini, primeiro no movimento a favor da entrada da Itália na Primeira Guerra Mundial, ao lado dos Aliados, e, depois, na instauração do regime fascista. O texto mostra como Teresina se manteve completamente imune às ilusões em que muitos incorreram em relação a Mussolini e seu regime. Assim, depois que Edmondo Rossoni, que fora seu amigo no Brasil, lhe enviou uma carta onde exaltava a Itália fascista, pela qual estava trabalhando numa posição de mando, a única resposta foi: 
Esta sua firmeza parece tanto mais notável quando pensamos em quantos se iludiram na época.

Enfim, o texto de Antonio Candido nos coloca diante de uma realidade humana e histórica abordada em profundidade, com característica de ensaio, e foi por isso que o denominei assim. Ao mesmo tempo, o evidente fundo autobiográfico leva a designá-lo como obra confessional. Mas, pensando melhor, tendemos a reconhecer que Teresina sai das páginas do livro com as características de uma figura de ficção, e em vista disso, o texto acaba aparecendo como verdadeira novela, não obstante o acúmulo de fatos reais meticulosamente documentados. E isto me leva a pensar mais uma vez em como se tornaram elásticos os limites entre os gêneros.

Os exemplos estão aí, às dezenas, às centenas. E na obra de Antonio Candido temos inúmeras demonstrações de como uma construção ensaística, mas com algo de ficcional, acrescenta um toque especial ao texto.

Tome-se, por exemplo, em O observador literário, ${ }^{3}$ um escrito bastante curto, "As cartas do voluntário", baseado nas cartas enviadas à família em Araraquara por Pio Corrêa da Rocha, voluntário na Guerra do Paraguai, promovido a tenente por atos de bravura e morto em ação. O "observador literário" não deixa de estar presente, com anotações pertinentes sobre o estilo das cartas, mas tudo em função da situação humana ali descrita.

Outro momento forte em que Antonio Candido reconstitui o sabor e perfume de uma época é, sem dúvida, "Adoniran Barbosa". O texto vinha na capa de um disco de vinil, que logo desapareceu do mercado e que eu não pude readquirir depois que alguém o afanou de mim, mas também não o encontrei na discoteca municipal de São Paulo, aonde fui justamente por causa do texto de capa. ${ }^{4}$

Ele tem umas três páginas apenas, mas nos diz tanto com aquela evocação dos diversos tempos da cidade de São Paulo e da figura inesquecível de Adoniran.

Agora, felizmente, já podemos lê-lo em livro, graças ao volume Textos de intervenção, organizado por Vinicius Dantas. ${ }^{5}$

Tratei aqui de uns poucos exemplos de escritos de Antonio Candido. Eles me fazem, no entanto, pensar em como o elemento novelesco e, mesmo, um toque de poesia incutem sabor a tantas páginas de nosso ensaísta e reafirmam a minha crença na importância da mistura de gêneros como uma das características da realização plena em termos de prosa moderna. E certamente me reasseguram quanto à justeza do caminho trilhado, quando surgem críticas (atualmente bem mais raras, é verdade) sobre a falta de unidade de gênero em alguns de meus textos.

\footnotetext{
${ }^{3}$ Antonio Candido. O observador literário. São Paulo, Conselho Estadual de Cultura do Estado de São Paulo, 1959, pp. 100-106.

4 "Adoniran Barbosa", disco lançado em 1975 (LP Odeon 51 C 062 421112).

${ }^{5}$ Antonio Candido. Textos de intervenção, seleção, apresentação e notas de Vinicius Dantas. São Paulo, Duas Cidades/Editora 34, 2002, pp. 211-213.
} 